FACULDADE DE CIÊNCIAS ECONÔMICAS DA UFRGS
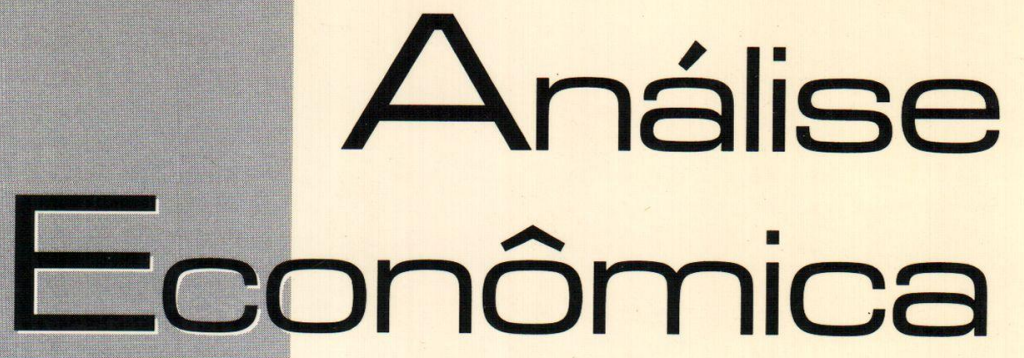

A CIÉNCIA ECONOMICA NA EUROPA E NOS Estados Unidos: PluRAlismo Versus MONISMO

ANTONio Maria da SiLveira

A EXPANSÃO DO COMERCIO MUNDIAL: IMPLICACOO ES SOBRE A HIPÓ TESE DE CONVERGENCIA

MANOEL BOSCO DE ALMEIDA

O SETOR AGRICOLA NA ÁREA DE LIVRE COMERCIO DAS AMÉRICAS: DESAFIOS DA INTEGRAÇÃO REGIONAL

PAULO D. WAQUIL.

PEQUENOS E MEDIOS FABRICANTES DE BENS DE CAPITAL FRENTE AS MUDANÇAS NA ECONOMIA BRASILEIRA

HOYEDO NUNES LINS

RISCOS NA ATIVIDADE BANCÁRIA EM CONTEXTO DE ESTABILIDADE DE PREÇOSE DE ALTA INFLAÇÃO

LUIS FERNANDO RODRIGUES DE Paula

O FIO DA NAVALHA DE HARROd EA RESPOSTA DA ESCOLA DE CAMBRIDGE MARIo AUGusto Bertella

A DINAMMICA FINANCEIRA INTERNACIONAL E A TENDENCIA Ã DOLARIZAÇÄO DAS ECONOMIAS LATINO-AMERICANAS

MARCOS ANTONIO MACEDO CinTRA

TEMPORALIDADE DA RIQUEZA - TEORIA DA DINAMMICA E FINANCEIRIZAÇÃO DO CAPITALISMO - RESENHA

Gentil Corazza

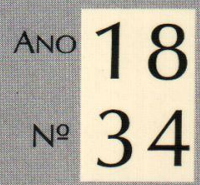


Universtode Federal do Rio Grande do Sul

Reitora: Prof ${ }^{a}$. Wrana Maria Panizzi

Faculdade de Crências Econômicas.

Diretora: Prof ${ }^{4}$. Otilia Beatriz Kroeff Carrion

Centro de Estudos e Pesquisas Econômicas

Diretor: Prof. Fernando Ferrari Filho

Departamento de Ciências Económicas

Chefe: Prof. Luiz Alberto Oliveira Ribeiro de Miranda

Departamento de Crências Contábeis e Atuariais

Chefe: Prof. João Marcos Leão da Rocha

Curso de Pós-Graduação em Economia

Coordenador: Prof Marcelo Savino Portugal

Curso de Pós-Graduação em Desenvolvimento Rurai

Coordenador: Prof Carlos Guilherme A. Mielitz Netto

Consel.ho Eomorial: Achyles B. Costa, Aray M. Feldens, Carlos A Crusius, Carlos G. A Mielitz Netto, Eduardo A. Maldonado Filho, Eduardo P. Ribeiro, Eugênio Lagemann, Fernando Ferrari Filho, Gentil Corazza, Jan A. Kregel, Marcelo S. Portugal, Nali J. Souza, Otília B. K Carrion, Paulo A. Spohr, Paulo D. Waquil, Pedro C. D. Fonseca, Philip Arestis, Roberto C. Moraes, Ronald Otto Hillbrecht, Stefano Florissi, Eleutério F. S. Prado (USP), Fernando H Barbosa (FGV/RJ), Gustavo Franco (PUC/RJ), João R. Sanson (UFSC), Joaquim P. Andrade (UnB), Juan H. Moldau (USP), Paul Davidson (Univ of Tennessee), Werner Baer (Univ. of Mlinois)

Comissāo Eoitonial: Eduardo Augusto Maldonado Filho, Fernando Ferrari Filho, Gentil Corazza, Marcelo Savino Portugal, Paulo Dabdab Waquil, Roberto Camps Moraes.

EdITor: Gentil Corazza

EdrTor Adjunto: Pedro Silveira Bandeira

Secretarus: Márcio Souza de Vargas

REVISĩo de teXtos: Vanete Ricacheski

Fundador: Prof. Antônio Carlos Santos Rosa

Os materiais publicados na revista Análise Econômica são da exclusiva responsabilidade dos autores. É permitida a reprodução total ou parcial dos trabalhos, desde que seja citada a fonte. Aceita-se permuta com revistas congêneres. Aceitam-se, também, livros para divulgação, elaboração de resenhas e recensões. Toda correspondência, material para publicação (vide normas na terceira capa), assinaturas e permutas devem ser dirigidos ao seguinte destinatário:

Prof. Genth Corazza

Revisia Anáxise Econômica - Av. João Pessoa, 52 CEP 90040-000 PORTO ALEGRE - RS, BRASIL

Telefones: (051) 316-3513 316-3440 - Fax: (051) 316-3990 rae@vortex.ufrgs.br

Análise Econômica

Ano $18, n^{\circ} 34$, setembro, 2000 - Porto Alegre

Faculdade de Ciências Econômicas, UFRGS, 2000

Periodicidade semestral, março e setembro

1. Teoria Econômica - Desenvolvimento Regional Economia Agrícola - Pesquisa Teórica e Aplicada -

Periódicos. I Brasil

Faculdade de Ciências Econômicas,

Universidade Federal do Rio Grande do Sul.

CDD 330.05

CDU $33(81)(05)$ 


\title{
A dinâmica financeira internacional e a tendência à dolarização das economias latino-americanas
}

\author{
Marcos Antonio Macedo Cintra \\ Em homenagem à professora Lenina Pommeranz
}

\begin{abstract}
Resumo: Após delinear a dinâmica do novo regime monetário-financeiro americano, sua expansão pelo resto do mundo e as principais propostas de reorganização da ordem financeira internacional, procuramos mostrar o aprofundamento da internacionalização dos sistemas financeiros e a dolarização crescente dos países latino-americanos. Em seguida, tentamos argumentar que esses processos de integração financeira estão reduzindo a capacidade dos bancos centrais latino-americanos implementarem políticas monetárias e cambiais autônomas e, portanto, de executarem políticas de desenvolvimento.
\end{abstract}

Palavras-chave: Sistema financeiro internacional, dolarização, política cambial.

Abstract: The author first outlines the dynamics of the new US financial and monetary regime, its expansion to the rest of the world and major proposals for the rearrangement of the international financial order. Secondly he shows the deepening of globalization of financial systems and increasing dollarization at Latin American economies. The author argues that these financial integration processes have been reducing the ability by Latin American central banks to implement monetary and exchange policies and therefore to carry out development policies.

Key-words: International financial system, dollarization, monetary policies.

\section{A dinâmica do sistema financeiro americano: aberto e integrado}

Os Estados Unidos dispõem hoje, em relação a qualquer nação, o mais amplo mercado de capitais e de investidores altamente sofisticados. A expansão da lógica financeira de valorização, característica dos seus mercados de capitais, iniciou a montagem de um novo esquema de fluxos financeiros que sintetiza quatro grandes movimentos. Isto é, a desregulamentação e a

\footnotetext{
${ }^{1}$ Doutor em economia pelo Instituto de Economia da Unicamp, pesquisador da Diretoria de Economia do Setor Público da Fundap e professor da Universidade Ibirapuera. Sou grato aos comentários de Alexandre Comin, Carlos E. Carvalho, Daniela M. Prates, Gentil Corazza, M. Cristina Penido de Freitas e Otaviano Canuto.
} 
liberalização financeira promoveram a interligação dos diferentes mercados nacionais, conformando um grande mercado global, a institucionalização da poupança financeira, o processo de securitização das dívidas e a expansão dos derivativos financeiros. Noutras palavras, a liberalização monetária e financeira, seguida pela desregulamentação dos mercados financeiros nacionais, pelo processo de securitização e pelos instrumentos derivativos constituíram um espaço financeiro verdadeiramente global, hierarquizado a partir do sistema financeiro americano.

$\mathrm{O}$ circuito financeiro que começa a se delinear é expressivamente mais complexo do que os anteriores, mesmo quando nestes se considerava a atuação dos agentes especuladores. Nesse circuito participa um maior número de agentes. O agente superavitário deposita os recursos nas empresas de administração de fundos (fundos mútuos, fundos de pensão, fundos de investimentos, hedge funds, companhias de seguro, etc.). Estes mantêm em suas carteiras de ativos securities diversas (títulos, notas, commercial papers, ações), emitidas pelos tomadores de recursos, mas também moedas, ouro, commodities, etc. As emissões de securities pelos tomadores (empresas produtivas, Estados soberanos, bancos internacionais ou de países em desenvolvimento) são realizadas através das instituições financeiras, que operam como broker (atuam como corretores de títulos e valores mobiliários, geralmente cobrando uma comissão). Os riscos de prazos e de crédito são bancados pelos fundos que compõem suas carteiras de ativos de forma a conseguirem carregar instrumentos de prazos mais longos através de depósitos de diferentes prazos. Além disso, os fundos figuram-se como emprestadores finais de recursos, enquanto os poupadores são os detentores de quotas destes. Assim, os riscos de perda do principal acabam pulverizados na malha de cotistas (pensionistas). A institucionalização dos especuladores termina por bancar o risco de preço (oscilações nas taxas de juros, câmbio, inflação, etc.), uma vez que a maioria das securities emitidas em diferentes moedas apresenta como características prazos relativamente longos e taxas de juros fixas. Essa atuação é pautada pela utilização dos derivativos financeiros, através dos quais os especuladores fazem trocas de taxas de juros fixas por flutuantes, ou de uma moedas para outra, entre os fundos e os tomadores de recursos (Mendonça, 1994, p. 59-60). As Agências de Classificação de Risco (Credit Rating Agencies) são outro grupo de agentes que passa a participar ativamente desse circuito. Sua função é montar parâmetros para a classificação de riscos dos diferentes agentes emissores de securities. A remuneração oferecida para cada instrumento lançado nesse mercado é estabelecida a partir dessa classificação ${ }^{2}$.

${ }^{2}$ Para uma discussão mais aprofundada sobre a dinâmica dos mercados monetários e financeiros dos Estados Unidos, ver Cintra (1997). 
É essa dinâmica financeira predominante na economia americana, característica dos seus mercados de capitais, que se impôs ao resto do mundo como paradigma, fornecendo a dinâmica da globalização financeira. Esta está ancorada nos títulos do Tesouro americano, na dimensão e sofísticação dos seus mercados de ativos privados (ações, títulos e moedas), nos portfólios diversificados dos investidores institucionais, nas operações cambiais estruturadas com instrumentos derivativos pelos bancos e na atuação das grandes empresas americanas que se transnacionalizaram, levando suas formas de produção e de gestão. Além disso, a moeda americana prevalece nas operações financeiras internacionais: $82 \%$ do valor nocional dos contratos de derivativos de câmbio no mercado de balcão têm o dólar como moeda em uma das pontas da operação, $50 \%$ das transações comerciais e $50 \%$ das transações no mercado primário e secundário de títulos são efetuadas em dólar.

A presença do dólar em pelo menos uma das pontas das operações de derivativos cambiais (swaps, opções e futuro) e de arbitragens nos principais mercados de câmbio e de títulos consolida a posição dominante da moeda americana nos mercados financeiros globalizados. Isso amplia a influência do dólar como referencial financeiro básico da economia internacional. A atratividade, qualitativamente superior, tanto das possibilidades de aplicação, como das facilidades de transações do mercado financeiro americano em relação a todos os outros, estabeleceu os alicerces de um capitalismo sobrepujado pelas finanças e a posição ocupada pelos Estados Unidos nesse processo.

Assim, os Estados Unidos, usufruindo seu poder financeiro, impõem a predominância de sua moeda, ao mesmo tempo em que mantêm um déficit elevado e persistente em conta corrente e uma posição devedora externa. Os mercados financeiros parecem dispostos a aceitar, a despeito das flutuações do valor do dólar, que os Estados Unidos exerçam, dentro de limites bastante flexíveis, o privilégio de emitir e gerir a moeda-reserva internacional. Dessa forma, os Estados Unidos, a partir de Washington e Wall Street, cumprem um papel fundamental na gestão da mundialização financeira: "o hot money conta, nos Estados Unidos, com um mercado amplo e profundo, onde imagina poder descansar das aventuras em praças exóticas. A existência de um volume respeitável de papéis do governo americano, reputados por seu baixo risco e excelente liquidez, tem permitido que a reversão dos episódios especulativos com ações, imóveis ou ativos estrangeiros -, seja amortecida por um movimento compensatório no preço dos títulos públicos americanos. Os títulos da dívida pública americana são vistos, portanto, como um refúgio seguro nos momentos em que a confiança dos investidores globais é abalada (como na crise mexicana de 1994 e dos países asiáticos em 1997)" (Belluzzo, 1997, p. 187). Isso significa que a função de reserva universal de valor, exercida pelo dólar, 
decorre fundamentalmente das características do mercado financeiro americano e do papel desempenhado pelo Estado americano, simultaneamente, como devedor e emprestador de última instância.

Nesse sentido, o papel contemporâneo exercido pelo dólar como reserva de valor não se circunscreve aos limites de um padrão monetário clássico (Tavares \& Melin, 1997). O valor do dólar decorre da capacidade de os Estados Unidos manterem sua dívida pública como título de segurança do sistema financeiro global. A taxa de juros americana, ao servir de referência para o crescimento das transações financeiras globais, induz a denominação das operações de securitização em geral (e, em particular, dos instrumentos de derivativos cambiais) em dólar.

Desde a "diplomacia do dólar forte", o Federal Reserve e o Tesouro exerceram um controle rigoroso sobre a taxa de juros e de câmbio. Além disso, como a riqueza financeira mundial está extremamente concentrada em títulos denominados na moeda americana, as decisões do Federal Reserve e do Tesouro são decisivas em seus processos de valorização/desvalorização. Assim, a política monetária americana tornou-se o principal mecanismo de regulação desse sistema de acumulação financeira que se globalizou. Vale dizer, a política monetária dos principais países tem uma tendência a se mover de forma interdependente com o Federal Reserve estabelecendo a direção básica. A interdependência dos sistemas financeiros nacionais num contexto de crescente liberalização dos movimentos de capitais, com portfólios cada vez mais plurimonetários, implica que uma simples tensão nas taxas dos títulos públicos de trinta anos do Tesouro americano pode abalar toda a estrutura das taxas de juros, e não apenas o segmento dos títulos. Por efeito indireto, afeta o segmento das ações e, através das exigências de margens, o segmento dos futuros de índices, etc.

Como maior devedor do mundo, os Estados Unidos dependem dos fluxos de financiamento do exterior e, portanto, da necessidade de garantir a confiança dos investidores nos títulos do Tesouro. Isso implica a manutenção de uma taxa de juros real positiva, fundando o que Chesnais (1996, p. 262) denominou regime de taxa de juros real positiva. Inicialmente muito elevadas (entre $12 \%$ e $8 \%$, etm termos reais, de 1980 a 1984), as taxas de juros foram progressivamente caindo, à medida que o regime de financiamento das demandas públicas e privadas nos mercados de capitais foram se estendendo para outros países.

Formou-se, então, a partir dos Estados Unidos um sistema financeiro aberto e integrado, que busca a manutenção de um rendimento real positivo. No sistema de crédito característico do pós-guerra, o relevante era a manutenção dos fluxos de financiamento pelos bancos comerciais e pelo Federal Reserve, mediante a 
utilização das operações de redesconto e da função de emprestador de última instância. Nos mercados de capitais contemporâneos o relevante é a permanente avaliação dos estoques, pois o ajuste ocorre pela variação dos preços dos ativos (Belluzzo, 1995, p. 15-6) ${ }^{3}$. A gestão dos estoques de ativos (cambial, acionário, de títulos e imobiliário) fica submetida a uma grande vulnerabilidade das taxas de juros às expectativas de inflação, a fim de manter um retorno real positivo. A taxa de inflação constitui uma ameaça permanente de desvalorização da massa de riqueza financeira.

O sistema torna-se intrinsecamente "desinflacionista": a necessidade de eliminar a inflação para evitar pronunciada e súbita reversão do ciclo de "inflação de ativos" e/ou ataques especulativos contra as moedas estabelece um viés deflacionário nas políticas macroeconômicas. "Aos primeiros sinais de aquecimento do nível de atividade e diante da percepção de que os ativos estão sobrevalorizados e de que as taxas de juros de longo prazo estão baixas - diante da inflação projetada - os agentes mais ágeis atiram primeiro e precipitam um sell off, provocando uma espiral baixista dos preços dos títulos e, conseqüentemente, as taxas de juros longas se elevam abruptamente. Com isso, o mercado emite sinais para as autoridades monetárias de que considera adequada e, ao mesmo tempo, inquietante a elevação das taxas de juros curtas. Isto explica, aliás, o aumento da volatilidade dos preços (e das taxas longas) durante as etapas de baixa do ciclo financeiro. Parece ser uma peculiaridade destes mercados de riqueza e de sua dinâmica cíclica, a endogenização dos movimentos da taxa de juros longa e a subordinação do manejo das taxas curtas às expectativas que comandam as alterações no curso das primeiras" (Coutinho \& Belluzzo, 1996, p. 133-4).

Nesse contexto, a política econômica dos diferentes países torna-se constantemente monitorada pelos mercados financeiros e qualquer medida julgada como incorreta desencadeia sanções imediatas - fugas de capitais, ataques especulativos, etc. - , reduzindo o raio de manobra das políticas nacionais. Os mercados interligados estabelecem um padrão de conduta econômica - liberalização financeira e cambial, com yield curves dos títulos de renda fixa e variáveis subordinadas às benchmarks internacionais; limites ao déficit fiscal; baixas taxas de inflação; sistemas de previdência privada, ampliando-se a atuação dos fundos de pensão nos mercados de capitais; e liberalização comercial - que praticamente não admite desvios, a despeito da imensa diversidade das realidades nacionais. Assim, o comportamento dos mercados financeiros passou a desempenhar um papel restritivo nas ações

${ }^{3}$ Sobre os processos de ajuste por variações de preços dos ativos, ver Goldstein et alii (1994, p. 2-6), que descreve a crise e os ajustes no mercado de bônus, no início de 1994. 
dos Estados, nas esferas fiscal, monetária e cambial. Por exemplo, se veicula-se a informação de que um determinado país está enfrentando dificuldades para controlar seu déficit público, os mercados financeiros internacionais tomam decisões que poderão resultar numa fuga de capitais, com conseqüente elevação da taxa de juros doméstica, seguida de uma desvalorização da moeda.

Enfim, os bancos centrais perdem autonomia na fixação das taxas de juros e de câmbio, tendo em vista a circulação financeira internacional fora do controle das autoridades monetárias. A disciplina imposta pelos mercados monetários e financeiros internacionais, cujos movimentos de antecipação podem destruir a estabilidade doméstica, acaba inibindo as tentativas de executar políticas ativas, destinadas à promoção do crescimento econômico e da renda, sobretudo quando implicam elevação do endividamento do setor público, uma vez que afetariam a credibilidade, diante dos mercados.

\section{As propostas de reorganização da arquitetura financeira internacional}

As crises dos países asiáticos, da Rússia, do hedge fund chamado LongTerm Capital Management e dos países latino-americanos entre 1997-99, desencadearam inúmeras discussões sobre a necessidade de uma nova arquitetura financeira internacional. No auge da crise, o próprio presidente dos Estados Unidos, Bill Clinton, chegou a afirmar que se estava diante da mais grave crise do capitalismo contemporâneo e determinou a formação de um grupo de trabalho para estudar a dinâmica do sistema monetário e financeiro (President's Working Group on Financial Markets formado por representantes do Department of the Treasury, do Board of Governors of the Federal Reserve System, da Securities and Exchange Commission e da Commodity Futures Trading Commission).

Simultaneamente, uma série de propostas foi surgindo para reformar a arquitetura do sistema financeiro internacional, clamando uma reinvenção das formas públicas e privadas de coordenação. Observa-se entre as alternativas para a prevenção das crises financeiras nos mercados liberalizados, desregulamentados e securitizados, que se procura evitar medidas de maior alcance, tais como o controle dos movimentos de capitais e a organização de um credor de última instância mundial. Deve-se considerar que, até o momento, os países exportadores de capitais têm sido afetados pela liberalização dos movimentos de capitais de forma muito mais positiva do que negativa. Assim, uma re-regulamentação dos fluxos internacionais de capitais somente seria possível se ocorresse uma crise dramática, que atingisse as economias centrais. 
As soluções que passam pelo mercado e, não por um fortalecimento das instâncias normativas e supranacionais, tendem a ser preponderantes entre as propostas defendidas pelos governos e pelas instituições de supervisão. Sobressai que os países precisam ser capazes de adequar-se às normas de um sistema financeiro mundial integrado sem contar com um credor internacional de última instância, mantendo livres os fluxos de capitais, com algum mecanismo "acordado internacionalmente" para tratar de reescalonamentos e moratórias, que ameaçam recorrentemente os "países em desenvolvimento". Isso significa que os países precisam de um sistema bancário fortemente capitalizado, com controles de supervisão prudenciais, rigorosos sistemas de acompanhamento dos passivos e ativos em moeda estrangeira, elevado volume de reservas internacionais, sólida posição fiscal, baixa taxa de inflação e taxa de câmbio com uma margem de flutuação razoavelmente livre, com o sistema financeiro e a política monetária dos Estados Unidos desempenhando o papel de gendarme mundial.

Significa também a adoção de padrões de conduta "aceitos internacionalmente", que aperfeiçoem a capacidade internacional de monitorar as políticas macroeconômicas domésticas, sobretudo no que se refere ao sistema financeiro e às políticas monetária, fiscal e cambial. O Fundo Monetário Internacional (FMI) já criou os "Padrões de Disseminação de Dados Especiais", o "Código de Boas Práticas em Transparência Fiscal" e o "Código de Boas Práticas em Política Monetária e Financeira". O Fundo está aperfeiçoando as formas de divulgação - no seu boletim na Internet - do desempenho comparativo dos diferentes países aos padrões preestabelecidos ("Práticas dos Países - Relatórios Experimentais na Observância dos Padrões e Normas"). Iniciou também a elaboração de um "Programa de Avaliação do Setor Financeiro", que pretende analisar a estabilidade deste setor em cada país, a partir de códigos e normas pertinentes (ver, http://www.imf.org) 4 . Diante dessas tendências, alguns analistas antevêem até a redução progressiva das moedas nacionais e, portanto, da autonomia na defĩnição das políticas macroeconômicas domésticas permitindo, aí sim, a coordenação financeira mundial. De acordo com o Ministro das Finanças do Equador, Alfredo Arízaga, "o continente americano terá uma moeda comum, mesmo que não seja o dólar. Alguns países podem ter de antecipar a troca de moeda se enfrentarem problemas de confiança em sua economia como o Equador" (Grinbaum, 2000).

${ }^{4} \mathrm{O}$ governo brasileiro assinou em junho de 2000 a declaração que permite a divulgação dos dados da economia brasileira nos padrões estabelecidos pelo FMI

${ }^{5}$ Ver também, Dornbusch (2000a), Tobin (1998). O prêmio Nobel de Economia de 1999, Robert Mundell, passou pela América Latina no mês de maio de 2000 e defendeu a criação de uma moeda e de um banco central único no Mercosul, como meio de atingir a integração regional no prazo de cinco anos A moedachamada de merc - deveria ser ancorada ao dólar (El Observador, 2000). 
A consolidação desses padrões de gestão das relações financeiras internacionais - a chamada nova "arquitetura financeira internacional" - começou na reunião que anunciou o aumento de capital do FMI (US\$ 90 bilhões), mediante elevação das cotas dos países membros, em 30 de outubro de 1998. Neste momento, os países do G-7 (Estados Unidos, Japão, Alemanha, França, Reino Unido, Itália e Canadá) decidiram:

a) criar linhas de crédito de curto prazo com caráter emergencial para atender aos países que aceitarem adotar as políticas econômicas exigidas pelo FMI;

b) solicitar a adoção de um código de conduta internacional pelas instituições financeiras (bancos e fundos de investimentos que operam em escala mundial), a fim de reduzir o grau de alavancagem e garantir a transparência das transações, sendo que o FMI supervisionaria a implementação dessas normas;

c) demandar aos organismos multilaterais a definição de "sistemas eficazes de falência e de relações entre credores e devedores";

d) recomendar ao setor privado o desenvolvimento de "mecanismos de financiamento de emergência";

e) sugerir que os mercados de capitais dos países emergentes fossem abertos de "modo cauteloso e ordenado".

\section{$3 \bigcirc$ aprofundamento da internacionalização do setor financeiro e a dolarização crescente dos países latino-americanos}

No final da década de 80 , os países periféricos ${ }^{6}$, em particular, os países latino-americanos, foram reinseridos, de forma subordinada, no sistema monetário e financeiro internacional. Após o movimento iniciado pelo México e Chile, em meados de 1987, todos os países latino-americanos foram promovendo investimentos de portfólio nos mercados de capitais domésticos; emissão de bônus, ações e recibos de depósitos de ações no mercado financeiro internacional; e entrada de bancos estrangeiros nos mercados nacionais para facilitar o saneamento dos sistemas. Além disso, o investimento estrangeiro direto, que era irrelevante em 1990, passou para um patamar de USS 54,1 bilhões em 1998, correspondendo a 3,4\% do PIB da região (ver tabelas 1 e 2).

No que se refere à entrada dos bancos estrangeiros nos mercados nacionais, verifica-se que, nos anos 90, os governos do Brasil e México ${ }^{7}$ promoveram

\footnotetext{
'Devemos esclarecer que entendemos como paises periféricos aqueles em que predomina "a natureza dinamicamente dependente do sistema produtivo, fragilidade monetária e financeira externa e subordinação político-militar" (Mello, 1997: 16).

${ }^{7}$ Até 1998, bancos estrangeiros poderiam adquirir apenas bancos mexicanos que controlassem $4 \%$ ou menos do mercado. No início de 1999, o Congresso aprovou nova lei permitindo que esse limite alcançasse $20 \%$ do mercado, para facilitar a privatização do Serfin, terceiro maior banco do país (Conger, 1999a)
} 
o aprofundamento da abertura do setor financeiro, procurando consolidar os sistemas, seja pela liquidação dos bancos mais frágeis, seja facilitando a absorção pelas instituições mais hígidas, sobretudo estrangeiras. Vale destacar a compra pelo $\mathrm{ABN}$ Amro Bank de $40 \%$ dos ativos do Banco Real brasileiro, que não apresentava dificuldades financeiras, surpreendendo o mercado. Tratou-se do maior negócio da história latino-americana envolvendo dois bancos, com valor total estimado em US\$ 3 bilhões. Na Argentina, a possibilidade de entrada dos bancos estrangeiros já havia sido estabelecida pelas reformas implementadas na segunda metade dos anos 70. Nos anos 90, predominou um processo de expansão dos bancos estrangeiros, a partir de suas estratégias de concorrência, sobre os bancos nacionais mais frágeis (quadro 1).

Tabela 1: Fluxo líquido de capitais privados para os países emergentes, América Latina e Brasil

\begin{tabular}{|c|c|c|c|c|c|c|c|c|c|}
\hline & & & & & & & \multicolumn{3}{|c|}{ US\$ bilhões } \\
\hline & 1990 & 1991 & 1992 & 1993 & 1994 & 1995 & 1996 & 1997 & 1998 \\
\hline Total dos Mercados Emergentes & 47,7 & 123,8 & 119,3 & 181,9 & 152,8 & 193,3 & 212,1 & 149,2 & 64,3 \\
\hline Investimento Estrangeiro Direto & 18,4 & 31,3 & 35,5 & 56,8 & 82,6 & 96,7 & 115,0 & 140,0 & 131,3 \\
\hline Portfólio & 17,4 & 36,9 & 51,1 & 113,6 & 105,6 & 41,2 & 80,8 & 66,8 & 36,7 \\
\hline Empréstimos Bancários e Outros & 11,9 & 55,6 & 32,7 & 11,5 & $-35,5$ & 55,4 & 16,3 & $-57,6$ & $-103,3$ \\
\hline Total América Latina & 13,7 & 24,1 & 55,9 & 62,6 & 47,5 & 38,3 & 82,0 & 87,3 & 69,0 \\
\hline Investimento Estrangeiro Direto & 6,7 & 11,3 & 13,9 & 12,0 & 24,9 & 26,0 & 39,3 & 50,6 & 54,1 \\
\hline Portfólio & 17,5 & 14,7 & 30,3 & 61,1 & 60,8 & 1,7 & 40,0 & 39,7 & 33,0 \\
\hline Empréstimos Bancários e Outros & 10,5 & $-2,0$ & 11,7 & $-10,6$ & $.38,2$ & 10,6 & 2,7 & $-3,1$ & $-18,1$ \\
\hline Brasil & 8,1 & 3,1 & $14, \mathrm{I}$ & 12,0 & 10,0 & 33,1 & 35,2 & 20,5 & 17,1 \\
\hline Investimento Estrangeiro Direto & 0,3 & 0,1 & 1,9 & 0,8 & 2,0 & 2,8 & 10,0 & 15,5 & 25,2 \\
\hline Portfólio & 0,5 & 3,8 & 14,5 & 12,3 & 51,1 & 11,7 & 21,4 & 10,5 & 17,5 \\
\hline Empréstimos Bancários e Outros & 7,3 & $-0,8$ & $-2,3$ & $-1,2$ & $-43,2$ & 18,6 & 3,8 & $-5,5$ & $-25,4$ \\
\hline \multicolumn{10}{|l|}{ Memo } \\
\hline \multicolumn{10}{|l|}{ Variação nas Reservas Internacionais } \\
\hline Mercados Emergentes & 66,1 & 75,1 & 31,5 & 83,9 & 90,9 & 123,1 & 101,1 & 59,2 & 58,3 \\
\hline América Latina & 147 & 18,0 & 23,0 & 20,2 & $-4,3$ & 24,8 & 26,2 & 13,5 & $-9,9$ \\
\hline Brasil & $-0,1$ & 0,6 & 14,5 & 8,1 & 6,5 & 12,6 & 8,6 & $-7,5$ & $-8,2$ \\
\hline \multicolumn{10}{|l|}{ Conta Corrente } \\
\hline Mercados Emergentes & $.27,2$ & $.79,0$ & $-69,7$ & $-107,2$ & $-69,7$ & $-96,0$ & $-92,5$ & $.91,8$ & $-53,6$ \\
\hline América Latina & $-1,0$ & $-16,9$ & $-34,5$ & $-45,7$ & $.50,9$ & $-35,9$ & $-39,0$ & $-65,1$ & $-89,5$ \\
\hline Brasil & $-3,8$ & $-1,4$ & 6,1 & $-0,6$ & $-1,7$ & $-18,0$ & $-23,1$ & $-33,3$ & $-34,9$ \\
\hline \multicolumn{10}{|l|}{ Fluxo Privado em $\%$ do PIB } \\
\hline Mercados Emergentes & 0,8 & 2,0 & 2,5 & 3,5 & 2,7 & 3,0 & 3,0 & 2,0 & 0,9 \\
\hline América Latina & 1,2 & 2,0 & 4,4 & 4,4 & 3,0 & 2,3 & 4,5 & 4,3 & 3,4 \\
\hline Brasil & 1,8 & 0,8 & 3,6 & 2,7 & 1,8 & 4,7 & 4,5 & 2,6 & 2,2 \\
\hline
\end{tabular}

Fonte: Adams et alii (1999, p. 92-3) 
Tabela 2: Emissão de bônus, ações e empréstimos pelos países Latino-Americanos

\begin{tabular}{|c|c|c|c|c|c|c|c|c|}
\hline & & & & & & & \multicolumn{2}{|c|}{ US $\$$ milhões } \\
\hline$\cdots \cdots$ & 1991 & 1992 & 1993 & 1994 & 1995 & 1996 & 1997 & $1998:(a)$ \\
\hline Bônus (b) & 7085 & 12.933 & 28794 & 17990 & 23071 & 47.157 & 54.165 & 23.439 \\
\hline Ações & 3891 & 3876 & 6022 & 4604 & 962 & 3661 & 5.102 & 74 \\
\hline Empréstimos (d) & 8.576 & 4998 & 3.554 & 6394 & 7.711 & 18.674 & 26202 & 2788 \\
\hline Empréstimos Sindicalizados & & & & & & & & \\
\hline (d) & 3.348 & 4.562 & 6.309 & 3516 & 12.131 & 12304 & 30.853 & 74.52 \\
\hline Rendo Fixa (e) & 5.570 & 8.890 & 30776 & 11432 & 12.627 & 10.878 & 4.415 & 2.500 \\
\hline Outros Renda Fixa $(f)$ & 40 & 95 & 128 & 73 & 0 & 0 & 25 & 0 \\
\hline Total & 28.510 & 35.354 & 75.583 & 44.009 & 56.502 & 92.674 & 120.762 & 36.253 \\
\hline
\end{tabular}

Fonte: Adams et alii (1998, p. 26-7).

Notas: (a) Até maio de 1998;

(b) Inclui a emissão de Euro medium-term note (EMTN);

(c) Incluem bridge facilities, export/supplier/acceptance/buyer credits, revolving credits e overdraft facilities;

(d) Incluem mezzanine e tax-spared loans;

(e) Incluem note issuance facilities, commercial paper e certificados de depósitos;

(f) Incluem certificados de depósitos 
Quadro 1: Principais participantes da internacionalização bancária no México, Argentina e Brasil (1995-2000)

\begin{tabular}{|c|c|c|}
\hline Banco estrangeiro & Origem & Forma de expansão \\
\hline \multicolumn{3}{|l|}{ Móxico } \\
\hline $\begin{array}{l}\text { Banco Bilbao Vizcaya Argentaria } \\
\text { (BBVA) }\end{array}$ & Espanha & $\begin{array}{l}\text { Aquisição de } 63 \% \text { do grupo Probursa } \\
\text { Investiu no Banca Cremi y Banorie } \\
\text { Aquisição de } 32,2 \% \text { do Bancomer }\end{array}$ \\
\hline Bank of Montreal & Canadá & Aquisiçc̃o de 16\% do Bancomer \\
\hline Bank of Nova Scotia & Canadá & Aquisiçc̃o de $45 \%$ do capital do Banco Inveriat \\
\hline A G Alemania & Alemanha & Aquisição do controle dos bancos Banoro e Bancrecer \\
\hline Banco Santander & Espanha & $\begin{array}{l}\text { Instalação de subsidiárias e aquisição de } 51 \% \text { do capital do Banco } \\
\text { Mexicano } \\
\text { Aquisição do Banco Serfin }\end{array}$ \\
\hline $\begin{array}{l}\text { Hong Kong Shanghai Banking } \\
\text { Corporation (HSBC) }\end{array}$ & Reino Unido & Aquisição de $20 \%$ do capital do grupo financeiro Serfin \\
\hline JP. Morgan & EUA & Aquisição de $8 \%$ do Serfin \\
\hline $\begin{array}{l}\text { Banco Central Hispanoamericano } \\
(B C H)\end{array}$ & Espanha & Aquisição de $10 \%$ do capital do grupo financeiro Prima International \\
\hline $\mathrm{BCH}$ e BCB & $\begin{array}{l}\text { Espanha e } \\
\text { Portugal }\end{array}$ & Aquisição em conjunto de $40 \%$ do Bital \\
\hline Citibank & EUA & Aquisiçẫo do Banco Confia \\
\hline \multicolumn{3}{|l|}{ Argentina } \\
\hline HSBC & Reino Unido & Aquisição de $100 \%$ do Banco Roberts \\
\hline BankBoston & EUA & Expansão da rede de agências \\
\hline Santander & Espanha & Aquisiçõo de $51 \%$ do capital do Rio de la Plata \\
\hline Bank of Nova Scotia & Canadá & Aquisição de $100 \%$ do Banco Quilmes \\
\hline Grupo Socimer & Suiç̧a & Aquisição de 30\% do Patrícios \\
\hline Bankers Trust & EUA & Aquisição de $51 \%$ do copital do Banco Liniers Sudamericano \\
\hline Crédit Agricole & França & Aquisição de $33 \%$ do Bisel \\
\hline BBVA & Espantia & $\begin{array}{l}\text { Fusão entre o Banco Francés do Rio de la Plata e o Banco Credito } \\
\text { Argentino }\end{array}$ \\
\hline Citibank & EUA & Expansão da rede de agências \\
\hline \multicolumn{3}{|l|}{ Brasil } \\
\hline HSBC & Reino Unido & Aquisição dos ativos do Banco Bamerindus \\
\hline Crédit Suisse & Suíça & Aquisição do Banco de Investimento Garantia \\
\hline Nations Bank & EUA & Aquisição de $51 \%$ do copital do Banco Liberal \\
\hline United Bank of Switzerland (UBS) & Suiça & Instalação de subsidiária com controle integral \\
\hline BBVA & Espanha & Aquisição do Excel-Econômico \\
\hline Rabobank & Holanda & Instalaçõo de sucursal \\
\hline Citibank & EUA & Expansão da rede de agências \\
\hline BankBoston & EUA & Expansão da rede de agências \\
\hline Santander & Espanha & Aquisiçẫo de $51 \%$ do Banco Geral do Comércio e do Noroeste \\
\hline Lloyds Bank & Reino Unido & Aquisição do Banco Multiplic e de sua financeira \\
\hline Crédit Agricole & França & $\begin{array}{l}\text { Aquisição de } 38 \% \text { do capital do Banco Boavista, em parceria com o grupo } \\
\text { porługuês Espírito Santo (38\%) e o brasileiro Monteiro Aranha (20\%) }\end{array}$ \\
\hline ABN-Amro Bank & Holanda & Aquisição de $40 \%$ do capirai do Banco Real. \\
\hline Chase Manhattan & EUA & Aquisiçcão do Búnco Patrimônio \\
\hline
\end{tabular}

Fonte: Freitas \& Prates (1998, p. 191-2), Camargo (1999), AP/Dow Jones (2000c) e AP/Dow Jones (2000d). 
A tabela 3 evidencia a extensão do processo de consolidação dos sistemas financeiros da América Latina, entre 1994 e 1997. Nesse período, desapareceram 127 bancos nos cinco principais países, mediante processos de liquidação, privatização, fusões e aquisições, sobretudo por instituições estrangeiras. Na Argentina, os bancos estrangeiros controlavam $21,7 \%$ dos ativos totais no final de 1994 e alcançaram $51 \%$ em maio de 1999 . No Brasil, a participação das filiais de bancos estrangeiros e dos bancos com participação total ou parcial de capital estrangeiro nos ativos do setor bancário saltou de $11 \%$ no final de 1994 para 24,6\% em dezembro de 1999 (Freitas, 2000). A privatização do Banespa no segundo semestre de 2000 poderá ampliar essa proporção, sendo que o Citibank, o Santander e o Bilbao Viscaya estão pré-qualificados para o leilão. No México, a participação dos bancos estrangeiros saltou de 1,2\% em dezembro de 1994 para 40\% em dezembro de 1998. Com a aquisição do Serfin pelo Santander e do Bancomer pelo BBVA, no segundo trimestre de 2000, restaram apenas dois bancos privados nacionais (Banamex e Banorte). No Chile, os bancos estrangeiros dominavam mais de $35,9 \%$ do total dos ativos do sistema financeiro, com o Santander sozinho detendo $28 \%$ dos ativos em 1999. Na Venezuela, após a falência do Banco Latino, o segundo maior banco do país, em janeiro de 1994, numa reação em cadeia, mais da metade dos 47 bancos comerciais do país necessitou auxílio financeiro da agência estatal garantidora dos depósitos e 16 foram nacionalizados ou fechados (The Economist, 1997). No processo de reestruturação, os bancos estrangeiros passaram a controlar $40,2 \%$ dos ativos do sistema bancário. Na Colômbia, os bancos estrangeiros detinham 28,8\% dos ativos bancários em dezembro de 1998. Com a fusão do Banco Wiese com o Banco de Lima Sudameris, os bancos estrangeiros passaram a controlar 58,5\% do mercado no Peru (Conger, 1999b).

Tabela 3: Número de instituições financeiras em países Latino-Americanos

\begin{tabular}{l|c|c|c} 
& 1994 & 1997 & Variacão \\
Argentina & 202 & 138 & -64 \\
Brasil & 271 & 233 & -38 \\
Chile & 37 & 32 & -5 \\
México & 36 & 53 & 17 \\
Venezuela & 129 & 109 & -20
\end{tabular}

Fonte: Adams et alli (1998, p. 39).

As estratégias de expansão do Banco Bilbao Vizcaya Argentaria (BBVA) e do Banco Santander Central Hispano (HSCH) pelos países latino-americanos merecem destaque. O Banco Bilbao Vizcaya Argentaria (BBVA) já adquiriu várias instituições em diversos paises (ver Quadro 2). No México adquiriu as redes de agências dos bancos Oriente e Cremi, as quais foram integradas ao 
BBV Prodursa, depois comprou 32,2\% do Bancomer, segundo maior banco do país. Com a aquisição do Bancomer, o BBVA passou a controlar $25 \%$ dos ativos bancários mexicanos e $10 \%$ dos ativos latino-americanos. Tornou-se o primeiro banco de depósitos e captação da América Latina, o segundo em ativos (seguido pelo Bradesco) e o primeiro grupo latino-americano na administração de fundos de pensão. Na Colômbia adquiriu a participação de $63 \%$ no capital do Banco Ganadero; na Venezuela, $51 \%$ do maior banco privado do país, o Banco Provincial; na Argentina, 60\% do capital do Banco Francés Rio de la Plata, o segundo banco privado do país; no Brasil assumiu o controle acionário do Excel-Econômico.

Quadro 2: Participação do Grupo Bilbao Vizcaya Argentaria em Bancos na América Latina

\begin{tabular}{|c|c|c|c|c|c|}
\hline Banco & Participação (\%) & $N^{\circ}$. de agências & Ativos totais & Ranking & Market Share (\%) \\
\hline $\begin{array}{l}\text { BBVA Banco Francés } \\
\text { (Argentina) }\end{array}$ & 60,0 & 260 & 8.859 & $2^{\circ}$ & 8,1 \\
\hline $\begin{array}{l}\text { Corporación Bancária } \\
\text { Argentina (Argentina) }\end{array}$ & 100,0 & nd & 400 & $20^{\circ}$ & nd \\
\hline $\begin{array}{l}\text { BBVA Excel-Econômico } \\
\text { (Brasill) }\end{array}$ & 100,0 & 217 & 5000 & $14^{\circ}$ & 1,1 \\
\hline $\begin{array}{l}\text { Banco Hipotecario de } \\
\text { Fomento (Chilel }\end{array}$ & 55,0 & nd & 2.960 & $6^{\circ}$ & 4,7 \\
\hline Banco Ganadero (Colômbia) & 63,0 & 250 & 3.526 & $2^{\circ}$ & 9,1 \\
\hline Probursa-BBVA México & 67,0 & 343 & 8.556 & $5^{\circ}$ & 7,5 \\
\hline Bancomer - BBVA & 32,2 & 1356 & 2.770 & $2^{\circ}$ & 19,0 \\
\hline Banco Continental (Peru) & 39,0 & 150 & 2864 & $3^{\circ}$ & 16,6 \\
\hline Bonco Provincial (Venezuelal & 51,0 & 320 & 4.186 & $1^{\circ}$ & 19,7 \\
\hline BBVA (Uruguail & 58,0 & nd & nid & $6^{\circ}$ & 4,3 \\
\hline BBVA (Panamá) & nd & nd & nd & $10^{\circ}$ & 3,0 \\
\hline BBVA (Porto Ricol & 100,0 & 65 & 3.580 & $3^{\circ}$ & 8,8 \\
\hline
\end{tabular}

Fonte: Calderón \& Casilda (2000, p. 78) e Conger (2000a).

Nota: (a) Posição dos ativos em US\$ milhões em dezembro de 1998

No início de 2000, o Banco Santander Central Hispano (HSCH) consolidou sua posição entre os maiores grupos financeiros da América Latina, controlando 17 bancos, inclusive no setor varejista, 11 administradoras de fundos de pensão, 12 gestoras de fundos de investimentos, nove companhias de seguro e 10 empresas de leasing e factoring em 12 países. Entre as aquisições efetuadas na região, que lhes garantiram $9,4 \%$ dos ativos bancários, sobressaem o Banco Rio de la Plata (Argentina), o Banco Osorno y La Unión e o Banco 
Santiago (Chile) ${ }^{8}$, o Banco Central Hispano (Porto Rico), o Banco Mexicano e Inver México e o $\operatorname{Serfin}^{9}$ (México), o Banco Comercial Antioqueño e Invercrédito (Colômbia) e o Banco de Venezuela (Venezuela) adquirido em leilão de privatização. No Brasil, o Santander investiu US\$220 milhões para comprar 50\% do capital total do Banco Geral do Comércio, US\$500 milhões na operação de compra do Noroeste e US\$ 1,3 bilhão na aquisição de $97 \%$ do capital do grupo Meridional, incluindo o banco de investimento Bozzano Simonsen.

Quadro 3: Participação do Banco Santander Central Hispano (BSCH) em bancos na América Latina

\begin{tabular}{|c|c|c|c|c|}
\hline Banco & & Participação (\%) & Ativos totais (a) & Ranking \\
\hline \multirow[t]{3}{*}{ Argentina } & Banco Galicia y Buenos Aires & 10,0 & 14.100 & $1^{\circ}$ \\
\hline & Río de la Plata & 51,0 & 9.175 & $2^{\circ}$ \\
\hline & Tornquist & 100,0 & 1.165 & $16^{\circ}$ \\
\hline Bolívia & Sonta Cruz & 90,0 & 1336 & $j^{0}$ \\
\hline \multirow[t]{3}{*}{ Brasil } & Banco Geral do Comércio (Santander Brasil) & 100,0 & nd & $11^{\circ}$ \\
\hline & Noroeste & 76,0 & 9.357 & $9^{\circ}$ \\
\hline & Meridional linclui o Bozzano Simonsenl & 97,0 & 8829 & nd \\
\hline \multirow[t]{2}{*}{ Chile } & Santiago & 44,0 & 10430 & $1^{\circ}$ \\
\hline & Osorno e La Unión (Santander Chile) & 86,0 & 9.709 & $2^{\circ}$ \\
\hline Colômbia & Comercial Antioqueño e Invercrédito (Santander Colômbial & 60,0 & 2.086 & $6^{\circ}$ \\
\hline \multirow[t]{3}{*}{ México } & Mexicano e Inver México ISantander Mexicanol & 71,0 & 9.808 & $5^{\circ}$ \\
\hline & Grupo Financeiro Bitol & 8,0 & 10.000 & $4^{\circ}$ \\
\hline & Grupo Financeiro Serfin S/A & 100,0 & 16.657 & $3^{\circ}$ \\
\hline Panamá & Centrobanco Hispano Panamá & 100,0 & nd & nd \\
\hline Paraguai & Banco de Asunción & 85,0 & 151 & $5^{\circ}$ \\
\hline \multirow[t]{2}{*}{ Peru } & Bancosur & 90,0 & 1.042 & $5^{\circ}$ \\
\hline & Mercantil e Interamericano ISantander Perul & 100,0 & 951 & $6^{\circ}$ \\
\hline \multirow[t]{2}{*}{ P. Rico } & Banco Central Hispano (Santander Puerto Rico) & 78,0 & 6468 & $2^{\circ}$ \\
\hline & $\mathrm{BCH}$ Internacional & 100,0 & 718 & nd \\
\hline \multirow[t]{2}{*}{ Uruguai } & Santander Uruguay & 100,0 & 740 & $3^{\circ}$ \\
\hline & Eurobanco $S / A$ & 100,0 & nd & nd \\
\hline Venezuela & Banco de Venezuela & 98,0 & 2.008 & $3^{\circ}$ \\
\hline
\end{tabular}

Fonte: Calderón \& Casilda (2000; p. 81) e AP/Dow Jones (2000c).

Nota: (a) Posição dos ativos em US\$ milhões de dezembro de 1998

${ }^{8}$ O BSCH passou a deter $43,5 \%$ do capital do Banco Santiago e $88 \%$ do Banco Osorno y La Unión (Santander Chile) Com essas aquisições passou a controlar $28 \%$ dos ativos totais do sistema financeiro chileno e $28,2 \%$ dos empréstimos A fim de controlar o grau de concentração do sistema financeiro, a Superintendência de Bancos está exigindo uma redução da participação do BSCH. Foi estabelecida uma meta, em que a participação de um unico banco não deve superar $20 \%$ dos ativos totais (Gazeta Mercantil Latino-americana, 2000)

${ }^{9}$ Com a aquisição do Serfin em leilão de privatização, o Santander passou a deter $18 \%$ dos ativos bancáríos mexicanos 
No México e na Argentina, da mesma forma que em outras economias menores, como por exemplo, na Bolívia e no Peru, a internacionalização dos sistemas financeiros foi acompanhada por uma tendência à substituição da moeda nacional pelo dólar em suas transações domésticas, como observado nas experiências do Cone Sul no final dos anos 70 (Damill, Fanelli \& Frenkel, 1996 e Cintra, 1999b) ${ }^{10}$. No México, mais de $30 \%$ do total de ativos das instituições privadas estão em dólar. Os títulos públicos mexicanos foram o segmento mais dolarizado, até o início do ano 2000. Na Argentina, 61\% dos depósitos bancários eram denominados em dólar. Se a Argentina mantiver seu currency board, seu sistema financeiro será mais internacionalizado e sua economia, cada vez mais dolarizada. No Peru praticamente $70 \%$ dos depósitos bancários estão em dólar (Katz, 2000). Em 1998, os depósitos em moeda estrangeira no Uruguai representaram $80,7 \%$ do total, constituindo US\$ 9,8 bilhões do total depositado (US\$12,1 bilhões), que corresponde a $51 \%$ do PIB (Fernández, 1999) ${ }^{11}$. O grau de dolarização do sistema bancário brasileiro, como um todo e por tipo de instituição, ainda é pequeno, em torno de $20 \%$ do total de ativos das instituições privadas. Não há, portanto, uma exposição predominante de risco cambial no setor bancário brasileiro. Os débitos externos estão «ancorados» no hedge correspondente, estabelecido em títulos públicos com indexação cambial.

\section{Conclusão}

Indo ao encontro do debate dominante sobre a nova ordem financeira internacional, observa-se que, no final da década de 90, predomina na América Latina as posições que defendem a implementação de políticas que aprofundem a desregulamentação dos sistemas financeiros domésticos - redução dos mecanismos de direcionamento compulsório de créditos e das restrições para determinadas operações - e, ampliem a integração com o mercado financeiro internacional, mediante um aperfeiçoamento das regras de supervisão financeira, dos instrumentos de administração de risco das próprias instituições e das exigências de capitais mínimos (Acordo de Basiléia) ${ }^{12}$. A tendência em

\footnotetext{
${ }^{10}$ Os bancos estrangeiros por suas relações com a matriz e com os mercados financeiros internacionais tendem a ampliar suas participações na captação e gestão de recursos externos nos mercados domésticos. No Brasil, por exemplo, a participação dos bancos estrangeiros na captação de financiamento internacional saltou de 34,6\% em junho de 1995 para 49,9\% em dezembro de 1998 (Freitas, 1999).

$"$ Nos anos 90 , os depósitos de não residentes duplicaram-se no Uruguai, atingindo US\$ 4,6 bilhões no fim de 1997, quase $25 \%$ do PIB do país.

${ }^{12}$ Sobre a participação do Brasil na reorganização da nova ordem financeira internacional, ver (Braga \& Cintra, 1999).
} 
aprofundar a associação dos capitais domésticos com os mercados financeiros internacionais é cada vez mais evidente, sobretudo, no que se refere aos mecanismos de financiamento de longo prazo, em três vertentes principais:

a) ampliar as alianças entre empresas, principalmente nos setores em expansão, tais como petróleo, telecomunicações e energia elétrica;

b) amplificar as captações nos mercados de capitais, utilizando os chamados processos de securitização (inclusive, securitização de recebíveis) e os project finance;

c) aumentar o acesso dos agentes econômicos domésticos ao mercado internacional de crédito, a partir da maior presença dos bancos internacionais no mercado financeiro interno.

Assim, a partir da natureza, da lógica e da predominância da defesa dos processos de aprofundamento da integração financeira e da participação da moeda americana nas transações domésticas dos países latino-americanos, defendemos a hipótese de que a nova ordem financeira internacional será, cada vez mais, comandada pelos mercados livres e desregulamentados e, portanto, haverá uma tendência à dolarização dessas economias, exceto, no Brasil. Tendo em vista a desproporção entre o estoque de ativos monetários em reais que deveriam ser convertidos em dólares e o volume de reservas do Banco Central, bem como a relativa incapacidade do comércio exterior de gerar saldos em moeda forte, a conversão somente poderia ocorrer mediante uma megadesvalorização cambial que, na prática, significaria um calote sobre a dívida pública.

O presidente do Banco Central da Bolívia, Juan Antonio Morales, afirmou que "a dolarização dos países latino-americanos é uma questão de tempo. Não se trata de decidir se ela ocorrerá ou não, mas de buscar formas para que ocorra com menos sofrimento. Do ponto de vista técnico, as economias da Argentina, Bolívia, El Salvador, Equador, México, Peru e Uruguai já estão irremediavelmente atreladas ao dólar. Em alguns casos, emprega-se a palavra dolarização, em outros não, mas esses países já abdicaram da prerrogativa de ditar suas próprias políticas monetárias" (Folha de São Paulo, 2000b).

Com moedas fracas, esses países estão se defrontando com o risco permanente de crises cambiais e financeiras. Assim, para manter suas contas de capitais dos balanços de pagamentos abertas, os países latino-americanos vão ficando diante do seguinte dilema: se optarem por defender suas moedas nacionais, mantendo algum grau de autonomia, ficam sujeitos a ataques especulativos periódicos. Então, vão aprofundando a dolarização nas transações domésticas e renunciando à soberania monetária ${ }^{13}$. Se decidirem pela moeda do país dominante,

${ }^{13}$ Conforme Carlos Soares Doria da consultoria Ecolatina: "independentemente de o governo querer ou não dolarizar a economia argentina, aos poucos isso está sendo feito pelo mercado" (Adachi, 2000) 
com a expectativa de uma convergência entre as taxas de juro doméstica e internacional e, de uma estabilidade nos fluxos de capitais pela eliminação do risco cambial, entregam as funções de administração do crédito, de provedor de liquidez e de emprestador de última instância ao Federal Reserve, e, assim, renunciam à soberania monetária. A submissão absoluta poderia ser concretizada nos regimes de currency board ou na adoção pura e simples do dólar. Adotando tais soluções, procurariam aprofundar a internacionalização do sistema financeiro, uma vez que os bancos estrangeiros possuiriam vantagens comparativas nas transações efetuadas em dólar nos mercades internacionais ${ }^{14}$.

De qualquer forma, os países foram se defrontando com a necessidade de adotar a moeda forte, como afirmou o presidente do Banco Nacional de Desenvolvimento Econômico e Social (BNDES), Francisco Gross, "o alinhamento ao dólar seria um dos padrões de boa conduta que se impõem a todos que desejam ter acesso aos mercados globais". Sabemos que a Argentina optou pela paridade entre o peso e o dólar desde 1991, construindo um percurso praticamente sem volta, pois $65 \%$ das dívidas públicas e privadas já se encontram em dólar. O Equador decidiu pela dolarização plena no início de $2000 .^{15}$ Grande parte dos pequenos países da América Central, altamente dependentes do mercado de bens e de transferências unilaterais dos Estados Unidos, dificilmente resistirá por muito mais tempo ${ }^{16}$.

Em meados de novembro de 1999, o Banco Central do Brasil anunciou que pretende instituir a livre conversibilidade do real - a possibilidade de trocar moeda nacional por estrangeira sem restrições - no ano de 2000. Atualmente, as pessoas físicas somente podem comprar sem identificação até US\$10 mil em moeda estrangeira e parte da remessa de moeda estrangeira para o exterior deve

\footnotetext{
${ }^{14} \mathrm{~A}$ internacionalização do setor bancário do Equador, após a aprovação da dolarização no início do mês de março de 2000, está sendo sugerida pelo FMI, Banco Interamericano de Desenvolvimento (BID), Banco Mundial e Corporação Andina de Fomento como única possibilidade de recuperar a economia do país. Praticamente, $75 \%$ do sistema financeiro equatoriano faliram após a crise de 1998 (AP/Dow Jones, 2000a).

${ }^{15}$ A Superintendência de Bancos do Equador anunciou que os bancos devem realizar todas suas transações - conta corrente, poupança, cartões de crédito e investimentos - em dólar a partir de 13 de junho de 2000. Em abril, o governo começou a pagar o salário do funcionalismo público em dólar. Em 13 de setembro, as notas de sucre, a antiga moeda, serão retiradas de circulação (AP/Dow Jones, 2000b).

${ }^{16}$ A vitória do candidato oposicionista, Vicente Fox, na eleição presidencial mexicana em julho de 2000, desencadeou a seguinte proposta de Dornbusch (2000b) para manter a estabilidade monetária: "há uma solução miraculosa que ele (o presidente eleito) pode adotar e que pode mudar o México dramaticamente: uma âncora cambial. A adoção de um sistema de âncora, ou mais além, da plena dolarização da economia, eliminaria a crônica instabilidade monetária mexicana. A taxa de câmbio desapareceria e o México seria quase como o Texas ou Nova Jersey em suas relações com o dólar. Abolir o Banco Central mexicano - que funciona relativamente bem, mas tem um passado tenebroso - e vincular o peso ao dólar traria uma queda dramática nas taxas de juros, um boom no preço dos ativos e uma virada rumo a uma taxa de crescimento significativa no médio prazo. Não existe outra maneira de o México garantir esses benefícios no curto prazo".
} 
ser realizada pela chamada conta $\mathrm{CC}-5$ (criada originalmente para transações de investidores não residentes no país). Pelas novas regras, não haveria limites para a compra de moeda estrangeira pelas pessoas físicas e a remessa de moeda estrangeira para o exterior ficaria livre, tendo, porém, de ser declarada no Imposto de Renda. As contas em moeda estrangeira no país continuariam proibidas (Batista, 1999 e Pinto, 2000). Portanto, o Banco Central do Brasil também pretende aprofundar a liberalização dos movimentos de capitais, desregulamentando o mercado de câmbio, e oferecendo maiores facilidades e garantias para as remessas de rendimentos para o exterior.

A posição do governo americano a respeito da dolarização das economias latino-americanas modificou-se rapidamente. Uma aparente oposição, transformou-se numa defesa explícita, sobretudo no que se refere às dolarizações unilaterais. Permaneceram as resistências em aceitar o ônus de uma dolarização negociada, mediante acordos bilaterais ${ }^{17}$. Após o ataque especulativo ao real e a defesa da dolarização da Argentina pelo presidente Carlos Menen, Alan Greenspan, presidente do Federal Reserve, disse que "o acesso aos recursos do Fed não é algo que nós ou nossos colegas do Tesouro consideramos uma boa idéia, na verdade, nós nos oporíamos a isso" (Folha de São Paulo, 25.2.1999). Alguns meses depois, o subsecretário do Departamento de Estado dos Estados Unidos, Peter Romero, afirmou que o processo de dolarização da América Latina seria "inevitável". E foi mais longe, salientou que as crises cambiais recente na região colocavam em xeque o projeto do Mercosul e a estratégia brasileira de resistir a uma integração continental acelerada (Aith, 1999).

O senador republicano Connie Mack, presidente do Comitê Econômico Conjunto do Congresso, elaborou um projeto de lei, em que o Tesouro americano seria autorizado a reembolsar os países que adotassem a dolarização em $8.5 \%$ das perdas originadas pela renúncia em emitir suas próprias moedas. Segundo o senador, como muitas economias latino-americanas já estariam parcialmente dolarizadas, incentivar a adoção oficial da moeda americana poderia acelerar a estabilidade monetária e financeira dessas economias, uma vez que

\footnotetext{
${ }^{17}$ O governo argentino já apresentou sem sucesso ao governo americano duas propostas em que procurava formalizar a dolarização de sua economia. A primeira envolvia um Tratado de Associação Monetária com acesso às operações de redesconto do Federal Reserve, que deveria evoluir gradualmente para uma união monetária das Américas, com a progressiva adesão de outros paises e a criação de um banco central único regional (Pinto, 1999b). A segunda envolvia a devolução ao governo argentino pelo governo americano de $80 \%$ da perda de senhoriagem ao abandonar o peso pelo dólar como moeda corrente. $O$ volume de reservas argentinas e a taxa de juros internacional determinariam esse montante, que seria utilizado para garantir linhas adicionais de crédito no mercado internacional. Essas poderiam ser sacadas em caso de necessidade do mercado financeiro doméstico, ampliando as margens de segurança do processo de transição de um sistema ao outro (Pinto, 1999a)
} 
"a dolarização é o caminho para a América Latina", manter a estabilidade e recuperar o crescimento (Folha de São Paulo, 7.3.2000).

Ao contrário do que se apregoa - a dolarização, eliminando a incerteza cambial, eliminaria o risco do país e reduzira as taxas de juro domésticas para os níveis internacionais, permitindo maior estabilidade nos movimentos de capitais e, portanto, maiores taxas de investimento e de crescimento - os processos de dolarização implicam perda da capacidade de implementar política monetária, cambial, de expansão creditícia e de exercer a função de emprestador de última instância, sem as vantagens sinalizadas ${ }^{18}$. Na verdade, os movimentos de arbitragem e de formação de posições especulativas nos mercados de moedas e ativos determinam um alinhamento passivo dos ciclos de expansão e contração das economias nacionais às expectativas dos administradores da riqueza globalizada e da liquidez internacional (ver tabela 4). Após a recessão de 1999, associada com a retração dos fluxos de capitais, nos primeiros meses de 2000, ocorreu uma melhoria na percepção dos mercados e, portanto, nas condições de liquidez, expressa na redução dos spreads cobrados e no volume de recursos captados. Esse retorno dos fluxos de capitais deverá desencadear uma retomada do crescimento dos países latino-americanos da ordem de $2,7 \%$, segundo estimativa da Cepal.

As economias latino-americanas ficam passivamente expostas às ondas de otimismo e pessimismo inerentes aos mercados globalizados. Os surtos de liquidez e de endividamento externo - associados à elevação dos preços dos ativos (inclusive do câmbio) - são acompanhados por crises de confiança, fugas de capitais e profundos processos de ajustamentos recessivos. As economias ficam sujeitas, então, a violentas flutuações do produto e do emprego ${ }^{19}$.

\footnotetext{
${ }^{18} \mathrm{O}$ canto da sereia emitido pelos organismos multilaterais, sobretudo FMI, foi muito bem reproduzido por Troster (2000b): "É importante lembrar também que os juros de uma moeda dolarizada são muito mais baixos, os spreads bancários mais estreitos e a oferta de recursos mais abundante. Dessa forma, com mais recursos e a um custo muito mais baixo, teríamos uma formação de capital muito maior, num país carente de investimentos como o Brasil. Isso redundaria em taxas de crescimento mais altas e um nível de desemprego menor. Não só haveria um aumento dos investimentos internos, como também os investimentos externos estariam mais propicios a investir num pais com tanto potencial como o nosso, e sem o risco de desvalorização."

${ }^{19}$ Aparentemente, esses processos de aprofundamento da integração e da liberação financeira dos países latino-americanos são capazes de desencadear um dinamismo relativo, advindo dos investimentos estrangeiros diretos, mas não de gerar um desenvolvimento para absorver os 200 milhões de pobres que permanecem vagando por seus territórios.
} 
Tabela 4: Indicadores das economias Latino-Americanas

\begin{tabular}{l|r|r|r|r|} 
& 1997 & 1998 & 1999 & 2000 (a) \\
\hline Variação real do PIB (em \%) & 5,4 & 2,1 & $-0,6$ & 2,7 \\
Inflação (em \%) & 8,5 & 7,9 & 8,3 & 7,9 \\
Déficii Fiscal lem \% do PIB) & $-1,8$ & $-3,7$ & $-2,8$ & $-1,6$ \\
Conta Corrente lem \% do PIB) & $-3,3$ & $-4,5$ & $-3,1$ & $-3,3$ \\
Variação das Exporłações (em \%) & 8,9 & 5,6 & 3,8 & 6,9 \\
Entrada Líquida de Capital na América Latina (b) & 31,6 & 24,9 & $-3,2$ & nd \\
\hline
\end{tabular}

Fonte: FMI, Banco Mundial e Cepal.

Notas: (a) Estimativa;

(b) Saldo do pagamento do principal e juros da dívida externa e da entrada líquida de capital na América Latina e Caribe (em US\$ bilhões)

Assim, com o aprofundamento da abertura financeira internacionalização dos sistemas bancários e dolarização das transações domésticas - o âmbito de atuação dos Estados nacionais latino-americanos é enormemente reduzido, visto que afeta a capacidade de implementar políticas monetárias, cambiais e creditícias autônomas, justamente os principais instrumentos utilizados durante o chamado período desenvolvimentista, 1930-80 (Furtado, 1995). Desaparece, portanto, do horizonte latino-americano qualquer possibilidade de implementação de políticas ativas de desenvolvimento e/ou de industrialização. Tudo isso deverá atingir o seu paroxismo após 2005, quando se efetivar a liberalização prevista nos acordos da Área de Livre-comércio das Américas (Alca), podendo resultar na formação de um sistema neocolonial, vale dizer, a América Latina poderá se constituir num conjunto de protetorados dos Estados Unidos.

Finalmente, podemos nos perguntar se não haveria alguma forma de resistir a essas tendências, aparentemente, implacáveis. Uma política alternativa necessariamente deveria passar pela centralização dos movimentos cambiais que possibilitaria a retomada do controle sobre o dinheiro e o crédito doméstico, visto que a manutenção da conta de capitais relativamente aberta implicaria risco cambial e taxa de juros extremamente elevados. Além disso, os países latino-americanos deveriam adotar políticas ativas de exportações e de substituição de importações, para que o superávit comercial fosse capaz de financiar os fluxos de serviços da conta de transações correntes. Políticas semelhantes têm sido implementadas pela China e Índia, onde a inserção internacional tem sido efetuada de forma gradual e negociada e não de forma subordinada como na América Latina 


\section{Referências bibliográficas}

ADACHI, Vanessa (2000) "Depósito em dólar sobe US\$ 5 bilhões na Argentina após desvalorização do real”, Folha de São Paulo, São Paulo, 17 de maio, p. B-2.

ADAMS, Charles; MATHIESON, Donald J. \& SCHINASI, Garry (1999) International capital markets. Developments, prospects, and key policy issues. Washington, D.C.: International Monetary Fund (World Economic and Financial Surveys).

ADAMS, Charles; MATHIESON, Donald J.; SCHINASI, Garry \& CHADHA, Bankim (1998) International capital markets. Developments, prospects, and key policy issues. Washington, D.C.: International Monetary Fund (World Economic and Financial Surveys).

AITH, Marcio (1999) “Dolarização, para EUA, é inevitável”, Folha de São Paulo, São Paulo, 4 de maio, p. 2-1.

AP/Dow Jones (2000a) "Bancos no Equador vão iniciar operações em dólar", republicado na Gazeta Mercantil, São Paulo, 22 de março, p. B-4.

AP/Dow Jones (2000b) “Dólar ainda confunde pequeno comércio", republicado na Gazeta Mercantil, São Paulo, 27 de abril, p. A-19.

AP/Dow Jones (2000c) "BSCH compra Serfin e é líder na AL", republicado na Gazeta Mercantil, São Paulo, 9 de maio, p. B.4.

AP/Dow Jones (2000d) "Bancomer aceita oferta de US\$2,5 bi do BBVA", republicado na Gazeta Mercantil, São Paulo, 13 de junho, p. B-9.

AKYUZ, Yilmaz (2000) "The debate on the international financial architecture: reforming the reformers". Discussion Papers, No. 148. Geneva: United Nations Conference on Trade and Development.

AKYUZ, Yilmaz \& CRONFORD, Andrew (1999) "Capital flows to developing countries and the reform of the international financial system". Discussion Papers, No. 143. Geneva: United Nations Conference on Trade and Development.

BAER, Mônica; CINTRA, Marcos Antonio Macedo; STRACHMAN, Eduardo \& TONETO Jr., Rudinei (1995) "Os desafios à reorganização de um padrão monetário internacional". Cebrap/Funag/SGPL/PNUD. Revista Economia e Sociedade, No. 4, Campinas: IE/Unicamp. 
BALIÑO, Tomás J.T \& UBIDE, Ángel (2000) "El nuevo mundo de la banca", Finanzas \& Desarrollo, Vol. 37, No. 2. Washington, D.C.: IMF, Junio, p. 41-44 (http://www.imf.org/fandd).

BATISTA Jr., Paulo Nogueira (1999) "Conversibilidade!". Folha de São Paulo, São Paulo, 11 de novembro, p. 2-2.

BELLUZZO, Luiz Gonzaga de Mello (1995) “O declínio de Bretton Woods e a emergência dos mercados 'globalizados' ". Revista Economia e Sociedade, No. 4. Campinas: IE/Unicamp, p. 11-26.

BELLUZZO, Luiz Gonzaga de Mello (1997) "Dinheiro e as transfigurações da riqueza". in TAVARES, M. C. \& FIORI, J. L. (Orgs.) Poder e dinheiro: uma economia política da globalização. Rio de Janeiro: Ed. Vozes, p. 151193.

BERG, Andrew \& BORENSZTEIN, Eduardo (2000) «Debate sobre la dolarización». Finanzas \& Desarrollo. Vol. 37, No. 1. Washington, D.C.: IMF, Marzo, p. 38-41 (http://www.imf.org/fandd).

BOVIM, Eric (2000) «Briga entre BBVA e BSCH ganha escala mundial», AP/ Dow Jones, republicado na Gazeta Mercantil, São Paulo, 1 de junho, p. B5 .

BRAGA, José Carlos de Souza \& CINTRA, Marcos Antonio Macedo (1999) «Brazil's participation in the reorganization of international finances», in Friedrich Ebert Stiftung (Coord.) Studies on international financial architecture. Berlin (tradução brasileira «A participação do Brasil na reor* ganização das finanças internacionais», disponível no site http:// www.fes.org.br).

CALDERÓN, Álvaro \& CASILDA, Ramón (2000) "La estratégia de los bancos españoles en América Latina". Revista de la Cepal, No. 70. Santiado: Cepal, p. 71-90.

CALVO, Guillermo A. (2000) Testimony on full dollarization. Presented Before a Joint Hearing of the Subcommittees on Economic Policy and International Trade and Finance. Washington, D.C. April 22.

CAMARGO, Gustavo (1999) "O bônus (e os ônus) da internacionalização". Gazeta Mercantil Latino-americana, São Paulo, 28 de junho, p. 14.

CHESNAIS, François (Org.) (1996) La mondialisation financière: genèse, coût et enjeus. Paris: Syros (tradução brasileira $A$ mundialização financeira: gênese, custos e riscos. São Paulo: Xamã, 1998). 
CINTRA, Marcos Antonio Macedo (1999) Uma visâo crítica da teoria da repressão financeira. Campinas: Editora da Unicamp/São Paulo: Fapesp.

CINTRA, Marcos Antonio Macedo (1997) As transformações na estrutura do sistema financeiro dos Estados Unidos: a montagem de um novo regime monetário-financeiro. Campinas: IE/Unicamp (tese de doutoramento).

CONGER, Lucy (2000a) "Fusão pode criar gigante mexicano". Gazeta Mercantil Latino-americana, São Paulo, 8 de maio, p. 30.

CONGER, Lucy (2000b) "BBVA - Bancomer é o líder na AL". Gazeta Mercantil Latino-americana, São Paulo, 19 de junho, p. 29.

CONGER, Lucy (1999a) "Da restrição à abertura total". Gazeta Mercantil Latino-americana, São Paulo, 28 de junho, p. 18.

CONGER, Lucy (1999b) "Os estrangeiros crescem no Peru". Gazeta Mercantil Latino-americana, São Paulo, 28 de junho, p. 20.

COUTINHO, Luciano G. \& BELLUZZO, Luiz Gonzaga de Mello (1996) "Estabilização e finanças 'globalizadas' ". Revista Economia e Sociedade, No. 7. Campinas: IE/Unicamp, p. 129-154.

CUNHA, André Moreira \& PRATES, Daniela Magalhães (2000) “Instabilidade financeira nos anos 90: a reação conservadora", Revista Economia e Sociedade. Campinas: IE/Unicamp (no prelo).

DAMILL, Mário; FANELLI, José Maria \& FRENKEL, Robert (1996) «De México a México: el desempeño de América Latina en los 90». Revista de Economia Política, Vol.16, No. 4. São Paulo: Ed. Nobel, p. 115-142.

DORNBUSCH, Rudiger (2000a) «Países menores precisam abandonar suas moedas», Financial Times, republicano na Folha de São Paulo, São Paulo, 7 de janeiro, p. 2-5.

DORNBUSCH, Rudiger (2000b) «O México depois do PRI», Folha de São Paulo, São Paulo, 23 de julho, p. A-3.

ECONOMIST (The) (1997) Fragile, handle with care. A survey of banking in emerging markets. London, April 12. (Este survey foi republicado na Gazeta Mercantil, entre 16 e 29 de abril de 1997, São Paulo).

FERNÁNDEZ, Uncas (1999) “Disputa regional enxuga sistema”, Gazeta Mercantil Latino-americana, São Paulo, 28 de junho, p. 20.

FERNANDEZ-ARIAS, Eduardo \& HAUSMANN, Ricardo (1999) International initiatives to bring stability to financial integration. Washington, D.C.: Inter-American Development Bank/Office of the Chief Economist (http://www.iadb.org). 
FOLHA DE SÃO PAULO (2000a) "Dolarização é o caminho para a AL", Folha de São Paulo, São Paulo, 7 de março, p. 2-5.

FOLHA DE SÃO PAULO (2000b) "Dolaridade", Folha de São Paulo, São Paulo, 30 de abril, p. 1-8.

FOLHA DE SÃO PAULO (1999) "Fed nega crédito a países que venham a dolarizar economia", Folha de São Paulo, São Paulo, 25 de fevereiro, p. 22.

FREITAS, M. Cristina Penido de (2000) "Ajuste e reestruturação do sistema financeiro em perspectiva comparada: Brasil, Argentina e México". I Simpósio sobre Política Monetária e Sistema Financeiro. Rio de Janeiro: Faculdades IBMEC, 17 de maio (mimeo).

FREITAS, M. Cristina Penido de (1999) "A ampliação recente da participação estrangeira no sistema bancário brasileiro". Análise Econômica, Ano 17, No. 32. Porto Alegre: Faculdade de Ciências Econômicas da UFRGS, p. 31-49.

FREITAS, M. Cristina Penido de \& PRATES, Daniela Magalhães (1998) "Abertura financeira na América Latina: as experiências do Argentina, Brasil e México". Revista Economia \& Sociedade, No. 11. Campinas: IE/ Unicamp, p. 173-198.

FRENKEL, Roberto (Ed.) (1994) El fortalecimiento del sector financiero en el proceso de ajuste: liberalización y regulación. New York: Banco Interamericano de Desarrollo/ Buenos Aires: Centro de Estudios de Estado y Sociedad.

FURTADO, Celso (1995) «O pensamento econômico latino-americano. Entrevista de Celso Furtado a Carlos Mallorquín», Revista Novos Estudos, No. 41. São Paulo: Cebrap, p. 96-109.

GAZETA MERCANTIL LATINO-AMERICANA (2000) «BSCH será mais controlado», Gazeta Mercantil Latino-Americana, São Paulo, 8 de maio, p. 24.

G-7 Finance Ministers (1999) Strengthening the international financial architecture. Report to the Koln Economic Summit, Cologne, 18-20 June (http://www.g-7.org/pr3210b.html).

GOLDSTEIN, Morris; FOLKERTS-LANDAU, David et alii (1994) International capital markets. Developments, prospects, and policy issues. Washington, D.C.: International Monetary Fund (World Economic and Financial Surveys). 
GRINBAUM, Ricardo (2000) "Dolarização foi ato de desespero, diz ministro das Finanças do Equador". Folha de São Paulo, São Paulo, 17 de janeiro, p. 1-10.

KATZ, Ian (2000) "Dolarização no Equador pode contagiar continente". Business Week, republicano na Gazeta Mercantil, São Paulo, 20 de março, p. B-5.

MANAUT, Sérgio (1999) "Bancos espanhóis fazem a América", Gazeta Mercantil Latino-americana, São Paulo, 8-14 de novembro, p. 25.

MELLO, João Manuel Cardoso (1997) “A contra-revolução liberal-conservadora e a tradição crítica latino-americana", in TAVARES, M. C. \& FIORI, J. L. (Orgs.) Poder e dinheiro: uma economia política da globalização. Rio de Janeiro: Editora Vozes, p. 15-24.

MENDONÇA, Ana Rosa Ribeiro de (1994) Inovaçôes financeiras e o papel da autoridade monetária. Um estudo a partir da economia americana. Campinas: IE/Unicamp (Dissertação de Mestrado).

MUNDELL, Robert (1997) "Currency areas, common currencies, and EMU". America Economic Review, Vol. 87 (2), p. 214-216.

OCAMPO, José Antonio (1999) "La reforma financiera internacional: una agenda ampliada”. Revista de la Cepal, No. 69. Santiago: Cepal, p. 7-31.

(El) OBSERVADOR (2000) «Mundell defende Mercosul com moeda atrelada ao dólar», republicado na Gazeta Mercantil, São Paulo, 8 de maio, p. B-6.

PINTO, Celso (2000) «A liberalização continua», Folha de São Paulo, São Paulo, 6 de janeiro, p. 1-12.

PINTO, Celso (1999a) «Dolarização à la Argentina», Folha de São Paulo, São Paulo, 25 de maio, p. 1-7.

PINTO, Celso (1999b) «Os planos da Argentina», Folha de São Paulo, São Paulo, 13 de junho, p. 1-7.

STIGLITZ, Joseph (2000a) «Como tirar da chuva os países em desenvolvimento: princípios para uma próxima rodada». Revista Política Externa, Vol. 8, No. 4. São Paulo: Editora Paz e Terra/Núcleo de Pesquisa de Relações Internacional e Política Comparada/USP, p. 71-99.

STIGLITZ, Joseph (2000b) «O que eu aprendi com a crise mundial». Folha de São Paulo, São Paulo, 15 de abril, p. 2-7. 
TAVARES, M. da Conceição \& MELIN, L. E. (1997) «Pós-escrito 1997: a reafirmação da hegemonia norte-americana», in TAVARES, M. C. \& FIORI, J. L. (Orgs.) Poder e dinheiro: uma economia política da globalização. Rio de Janeiro: Ed. Vozes, p. 55-86.

TOBIN, James (1998) Financial globalization: can national currencies survive? Paper prepared for the Annual World Bank Conference on Development Economics. Washington, D.C.: World Bank (http://www.worldbank.org/ abcde/tobin.pdf).

TROSTER, Roberto Luis (2000a) “Que tal dolarizar o Brazil também?”. Folha de São Paulo, São Paulo, 15 de janeiro, p. A-3.

TROSTER, Roberto Luis (2000b) "O Brasil dolarizado". Jornal do Economista, Informe do Sindecon. São Paulo: Corecon, abril, p. 4-B.

VILAS, Oscar (1999) "Chilenos vão investir no exterior”. Gazeta Mercantil Latino-americana, São Paulo, 28 de junho, p. 20. 